УДК 342.924, 342.922

DOI https: / / doi.org/10.32837/yuv.v0i4.1981

\author{
Я. Михайлюк, \\ кандидат юридичних наук, адвокат \\ Адвокатського об'єднання «ТОТУМ»
}

\title{
АДМІНІСТРАТИВНЕ ОСКАРЖЕННЯ: СУЧАСНИЙ СТАН ТА ПЕРСПЕКТИВИ РОЗВИТКУ
}

Постановка проблеми. Забезпечення ефективного захисту прав і свобод громадян у відносинах з органами державної влади є однією з ключових рис демократичної та правової держави. Належне правове регулювання адміністративних процедур у вказаному контексті відіграє важливу роль.

Ефективне правове регулювання відносин між фізичними і юридичними особами та органами державної влади і місцевого самоврядування (органами публічної адміністрації) убезпечує від зловживань із боку останніх i, як наслідок, є запорукою забезпечення захисту прав та інтересів приватних осіб. Д.В. Лученко, наголошуючи на важливому значенні оскарження в адміністративному праві, вказує, «що оскарження рішень, дій або бездіяльності суб'єктів публічно-владних повноважень становить інститут демократії і чинник забезпечення демократичності Української держави» [1, с. 23].

Правове регулювання адміністративного оскарження $€$ складником інституту адміністративних процедур. Інститут адміністративних процедур в Україні потребує грунтовного оновлення i приведення у відповідність до найкращих світових практик правового регулювання відносин органів публічної адміністрації з приватними особами на основі принципів належного врядування.

Як зазначається в науковій літературі, «концепція належного урядування сформувалася в європейській правовій доктрині на основі та за умови дотримання двох основоположних принципів побудови правових систем провідних західноєвропейських країн - демократії та верховенства права» [2, с. 37].

Дослідження досвіду правового регулювання адміністративного оскарження у країнах ЄC має важливе значення в контексті адаптації українського законодавства до законодавства ЄC та вдосконалення процедур адміністративного оскарження в Україні.

Стан наукового дослідження. Дослідженням правового регулювання адміністративних процедур займалися такі вчені, як В.Б. Авер'янов, К.К. Афанасьєв, Ю.П. Битяк, І.П. Голосніченко, С.Л. Дембіцька, Т.О. Коломоєць, І.Б. Коліушко, Є.В. Курінний, Г.М. Писаренко, А.А. Пухтецька, А.О. Селіванов, В.П. Тимощук та ін. Інститут оскарження в адміністративному праві є предметом дослідження у працях Д.В. Лученка, А.Т. Комзюка, О.В. Кузьменко, Р.О. Куйбіди, В.Г. Перепелюка, С.Г. Стеценка, А.М. Школика та ін.

Метою статті $є$ дослідження сучасного стану правового регулювання адміністративного оскарження, вивчення зарубіжного досвіду оскарження актів публічної адміністрації та на основі порівняльного аналізу формулювання пропозицій та рекомендацій щодо вдосконалення українського законодавства в означеній сфері.

Завданнями статті $€$ :

- аналіз сучасного стану правового регулювання оскарження адміністра- 
тивних актів в Україні та основних законодавчих ініціатив щодо його вдосконалення;

- характеристика позитивних прикладів зарубіжного досвіду регулювання процедур оскарження актів публічної адміністрації;

- формулювання пропозицій та рекомендацій щодо вдосконалення правового регулювання адміністративного оскарження.

Виклад основного матеріалу. В юридичній літературі зазначають, що «з точки зору адміністративної процедури таке оскарження можна розглядати як один із видів адміністративної процедури або як iii факультативну стадію» [3, с. 206]. Поняття адміністративного оскарження та місце інституту адміністративного оскарження у правовій системі дискується в науковій літературі.

Зокрема, адміністративне оскарження розглядають як «Правовий інститут, який являє собою сукупність правових норм, що регулюють суспільні відносини, які виникають у зв'язку з реалізацією фізичною чи юридичною особою права на оскарження рішень, дій та бездіяльності органів виконавчої влади шляхом подання скарги до органу виконавчої влади (посадової особи), що уповноважений здійснювати їх розгляд та вирішення» $[4$, с. 8].

Також інститут адміністративного оскарження пропонують включати до комплексного інституту оскарження в адміністративному праві, до якого, окрім інституту адміністративного оскарження, входять також інститути судового оскарження та непрямого оскарження [1, с. 14].

В європейській адміністративно-правовій доктрині адміністративне оскарження розглядають значно ширше з точки зору суб'єктів, рішення, дії або бездіяльність яких можуть оскаржуватися. Зокрема, в порядку адміністративного оскарження можуть переглядатися акти всіх органів публічної адміністрації, в тому числі органів виконавчої влади, органів місцевого самоврядування, об'єднань громадян під час здійснення делегованих функцій публічного адміністрування, посадових осіб органів публічної адміністраціі.

Узагальнюючи результати дослідження правової природи адміністративного оскарження, варто виділити такі його ознаки:

- адміністративне оскарження виступає факультативною стадією адміністративної процедури, оскільки без попередніх стадій адміністративної процедури неможливим є оскарження рішень, дій чи бездіяльності адміністративного органу;

- адміністративне оскарження реалізується в межах системи органів публічної адміністрації (чи спеціально утворених комісій);

- порядок здійснення оскарження регламентований адміністративно-процедурними нормами;

- в Україні адміністративне оскарження не є обов'язковим перед зверненням до суду, однак у багатьох країнах адміністративне оскарження має обов'язковий характер;

- має безоплатний характер;

- за результатами адміністративного оскарження суб'єкт розгляду скарги може прийняти рішення, яким вирішить справу по суті, на відміну від судового розгляду;

- рішення, прийняте за результатами адміністративного оскарження, $€$ обов'язковим для виконання, проте може бути переглянуто в судовому порядку [5, с. 23].

Згідно 3 даними статистичних досліджень Ради Бізнес-омбудсмана в Україні адміністративне оскарження має високу популярність. Зокрема, серед 300 опитаних представників бізнесу у 2019 році, якщо є можливість оскаржити спірне рішення (дію, бездіяльність) державного органу спочатку в адміністративному порядку або ж одразу до суду, то 73,3 \% учасників опитування Ради спочатку подадуть скаргу в адміністративному порядку 
і лише 26,7\% одразу звернуться до суду $[6$, с. $7-8]$.

Однак довіра громадян до інституту адміністративного оскарження невисока, про що свідчать результати України згідно з Індексом Глобальної Конкурентоспроможності у 2018 році, за яким Україна посіла 107-е місце (зі 140 країн) за показником «Ефективність правових механізмів оскарження регуляторних актів».

Така ситуація зумовлена різними чинниками: як перевагами адміністративного оскарження порівняно із судовим, так і його недоліками.

Зокрема, серед основних переваг адміністративного оскарження для приватної особи варто виділити такі:

- доступність: подання скарги в порядку адміністративного оскарження не вимагає спеціальних знань, залучення адвоката та в переважній більшості може бути реалізовано особою самостійно, на відміну від судового оскарження, що в більшості випадків вимагає залучення адвоката;

- оперативність: строки розгляду скарг в порядку адміністративного провадження на практиці $€$ значно коротшими порівняно із судовим розглядом, що забезпечує дотримання принципу правової визначеності;

- безоплатність: адміністративне оскарження $€$ безоплатним, на відміну від судового, що в більшості випадків передбачає сплату судового збору, окрім винятків, коли судовий збір не сплачується;

- результативність: у результаті розгляду адміністративної скарги уповноваженим органом може бути прийнято рішення по суті, на відміну від судового розгляду, у випадках коли суд не може втручатися в дискреційні повноваження органів публічної адміністрації.

Незважаючи на вказані переваги, адміністративне оскарження в Україні не позбавлено таких недоліків, як:

- низька ефективність: у результаті розгляду більша частина скарг залишається без задоволення. Зокрема, під час розгляду податкових спорів відповідно до даних, розміщених на офіційному сайті Державної податкової служби України, в результаті адміністративного оскарження у 2019 році було скасовано 23,4\% оскаржуваних податкових повідомлень-рішень;

- суб'єктивність та упередженість: під час розгляду скарг у порядку адміністративного провадження відсутні ефективні механізми забезпечення неупередженості та безсторонності, які наявні під час розгляду справи у суді;

- відсутність реальних механізмів оскарження в окремих випадках: така ситуація має місце, зокрема, в разі відсутності органу вищого рівня, що може виступати суб'єктом розгляду скарги, наприклад, під час оскарження рішень органів місцевого самоврядування;

- залишається відкритим питання корупційних ризиків і загального рівня недовіри до органів державної влади в Україні, що значно вище, ніж у багатьох європейських країнах.

Узагальнюючи досвід правового регулювання адміністративного оскарження, західноєвропейські науковці виділяють «два основні типи адміністративних апеляцій: обов'язкова та диспозитивна (необов'язкова). Перший тип застосовується у великій кількості правових систем (серед яких Німеччина, Нідерланди, Угорщина, Словенія, Польща, Сербія, Данія, Чехія, Румунія), де виключається позов до суду за відсутності попереднього адміністративного оскарження. На рівні законодавства ЄC попередні адміністративні апеляції необхідні в окремих випадках: до відкриття Європейською Комісією процедур стосовно порушення законодавства Союзу державами-членами, у разі надання державного фінансування державами-членами, у випадках коли йдеться про доступ до документів ЄC, у справах про спори, пов'язані з державною службою в органах $\in C$ » [7, c. 540]. 
3 іншого боку, «другий тип апеляціï (фр. - recours administratif), що застосовується у французькій юридичній системі та частково в Бельгії, Італії, вказуючи на певні наслідки здійснення адміністративного оскарження (наприклад, продовження строків подання позову в судовому порядку), не визначає адміністративне оскарження як обов'язкове» [7, c. 541].

В українському законодавстві попереднє адміністративне оскарження перед зверненням до суду не $€$ обов'язковим. Відповідно до ст. 124 Конституції України юрисдикція судів поширюється на будь-який юридичний спір та будь-яке кримінальне обвинувачення. Однак у цій же статті закріплено положення про те, що законом може бути визначений обов'язковий досудовий порядок урегулювання спору, що фактично дає можливість на законодавчому рівні встановити обов'язкове адміністративне оскарження.

Законодавчі ініціативи 3 регулювання адміністративних процедур в Україні досі не увінчалися успіхом. Починаючи з 2001 року й дотепер, було підготовлено багато проєктів спочатку Адміністративно-процедурного кодексу, а пізніше Закону «Про адміністративну процедуру». Зокрема, сьогодні на розгляді у Верховній Раді України знаходиться черговий проєкт Закону України «Про адміністративну процедуру» № 3475 від 14.05.2020 року. Нещодавно відбулись перші зрушення в розгляді цього законопроєкту, його розглянуто та прийнято в першому читанні.

Однак вказаний законопроєкт не позбавлений недоліків, зокрема, в контексті адміністративного оскарження потребують уточнення положення щодо суб'єктів розгляду скарг.

Зокрема, в законопроєкті № 3475 збережено норму, яка містилася в попередніх законопроєктах, що суб'єктом розгляду скарги може бути утворено комісію з розгляду скарг, яка діє на громадських засадах. Причому рішення такої комісії мають рекомендаційний характер для органу державної влади. Науковці, досліджуючи інститут адміністративного оскарження, піддають критиці пропозицію щодо розгляду скарг спеціальною комісією, яка діє на громадських засадах. Д.В. Лученко, зазначає, що «недоліками правового регулювання діяльності комісій з розгляду скарг, що передбачене в проекті Адміністративно-процедурного кодексу України, $€$ те, що їх створення $є$ правом, а не обов'язком адміністративного органу, їхні рішення носять рекомендаційний характер, а склад цих комісій формується не на фаховій основі» [8, c. 228-229].

Звертаючись до зарубіжного досвіду адміністративного оскарження, варто звернути увагу на порядок розгляду адміністративних скарг. Зокрема, в Нідерландах відповідно до ст. 6:4 Акту загального адміністративного права передбачено два способи адміністративного оскарження: подання заперечення та подання адміністративної апеляції. Повідомлення про заперечення подається до адміністративного органу, який видав розпорядження. Адміністративна апеляція подається до апеляційного органу.

Відповідно до ст. 73 Закону про адміністративну процедуру Республіки Естонія заперечення подається через адміністративний орган, що видав адміністративний акт чи здійснив захід, адміністративному органу, що здійснює наглядовий контроль за адміністративним органом, що видав адміністративний акт чи здійснив захід, який заперечується. За відсутності адміністративного органу, що здійснює наглядовий контроль за адміністративним органом, що видав адміністративний акт чи здійснив захід, який заперечується, заперечення розглядається адміністративним органом, що видав адміністративний акт чи здійснив захід, який заперечується.

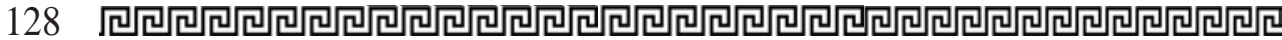




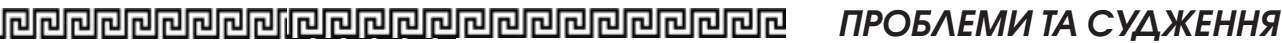

Згідно з параграфом 2 ст. 127 Кодексу про адміністративні провадження Республіки Польща компетентним для розгляду апеляцій є орган публічної адміністрації вищого ступеня, якщо законом не передбачений інший апеляційний орган.

Таким чином, в європейських країнах в основному розгляд скарг на адміністративні акти здійснюється або органом вищого рівня, або органом, що прийняв оскаржуване рішення, якщо орган вищого рівня відсутній. Причому неупередженість та об'єктивність під час розгляду скарг забезпечується через заборону посадовій особі, яка брала участь у прийнятті оскаржуваного акта, брати участь у розгляді скарги на нього.

Висновки та перспективи подальших досліджень. Аналізуючи сучасний стан правового регулювання адміністративного оскарження в Україні, варто зазначити, що наразі відсутнє його ефективне правове регулювання. Закон України «Про звернення громадян» містить застарілі положення та не відповідає сучасним вимогам до регулювання суспільних відносин. Правові норми про порядок адміністративного оскарження містяться в нормативно-правових актах різної юридичної сили.

Зазвичай порядок адміністративного оскарження $€$ різним залежно від сфери суспільних відносин, які регулюються тим чи іншим нормативно-правовим актом. Наприклад, Податковий кодекс України закріплює порядок оскарження рішень контролюючих (податкових та митних) органів, Закон України «Про державну реєстрацію юридичних осіб, фізичних осіб - підприємців та громадських формувань» установлює порядок оскарження рішень, дій та бездіяльності у сфері державної реєстрації тощо.

Загальний (рамковий) порядок адміністративного оскарження, який може застосовуватися незалежно від сфери суспільних відносин, сьо- годні відсутній. Звичайно, що вирішення цього питання $€$ частиною більш широкої проблеми і пов'язане 3 відсутністю загального нормативного акта, спрямованого на регулювання адміністративних процедур.

Доцільність та необхідність уніфікованого правового регулювання адміністративних процедур, у тому числі порядку адміністративного оскарження, підтверджена досвідом правового регулювання означених відносин у західноєвропейських країнах. Про ефективність такого правового регулювання свідчить як високий рівень довіри громадян до органів публічної адміністрації, так і широке застосування такого механізму i, порівняно з Україною, низький відсоток судового оскарження актів органів публічної адміністрації.

Подальшого дослідження потребують окремі аспекти правового регулювання адміністративного оскарження, вивчення зарубіжного досвіду правового регулювання аналогічних суспільних відносин 3 метою вдосконалення існуючого законодавства в означеній сфері та доопрацювання проєкту Закону України «Про адміністративну процедуру».

у статті проведено наукове дослідження сучасного стану правового регулювання адміністративного оскарження в Україні. Окрему увагу присвячено проблемі прийняття загального нормативно-правового акта щзодо регулювання адміністративних процедур. Проаналізовано переваги та недоліки адміністративного оскарження в Україні. Зокрема, до переваг адміністративного оскарження віднесено доступність, оперативність, безоплатність, результативність. Натомість серед недоліків, що притаманні адміністративному оскарженню, виділено такі як низька ефективнiсmь, суб'єктивність ma упередженість, відсутність реальних 
механізмів оскарження в окремих випадках.

Детально розглянуто проблему суб'єкта розгляду скарг на рішення, дії чи бездіяльність органів публічної адміністрації. Розгляд адміністративних скарг органом вищуого рівня є найефективнішим, однак не завжди такий орган наявний. У цъьому випадку в західноєвропейських країнах зазвичай застосовується механізм перегляду, тобто розгляд скарги здійснюеться органом, який видав оскаржуваний адміністративний акт. При цьому з метою забезпечення неупередженості та об'єктивності посадова особа чи особи, які видали оскаржуваний адміністративний акт, не можуть брати участь у розгляді такої скарги. Розгляд скарг на рішення, дії чи бездіяльність органів публінної адміністрації спеціальними комісіями з розгляду скарг не є ефективним, зважаючи на рекомендаційний характер їніх рішень та необов'язковість ї створення.

Проаналізовано досвід західноєвропейських країн у сфері правового регулювання адміністративного оскарження та виокремлено дві основні моделі адміністративного оскарження: обов'язкове та необов'язкове, кожна з яких наділена як перевагами, так $i$ недоліками.

За результатами проведеного дослідження наголошено на необхідності вдосконалення сучасного стану правового регулювання через прийняття єдиного акта щодо регулювання адміністративних процедур загалом, так і адміністративного оскарження зокрема.

Ключові слова: адміністративне оскарження, адміністративна процедура, оскарження актів органів публічної адміністрації, правове регулювання адміністративного оскарження, правове регулювання адміністративних процедур.
Mykhailiuk Ya. Administrative appeal: current state and development prospects

The article is a scientific study of the current state of legal regulation of administrative appeals in Ukraine. Particular attention is paid to the problem of adopting of general legal act regulating administrative procedures. The advantages and disadvantages of administrative appeal in Ukraine are analyzed. In particular, the advantages of an administrative appeal including accessibility, efficiency, free of charge, and effectiveness. Instead, the disadvantages of administrative appeal including low efficiency, subjectivity and partiality, lack of real mechanisms for appeal in some cases.

The problem of the subject of consideration of complaints against decisions, actions or inaction of public administration bodies is considered in detail. The consideration of administrative complaints by a higher level body is the most effective, but such a body is not always available. In this case, in Western European countries, the review mechanism is usually used. The review of the complaint is carried out by the body that issued the contested administrative act. However, in order to ensure impartiality and objectivity, the official or persons who issued the contested administrative act may not participate in the consideration of such a complaint. Consideration of complaints against decisions, actions or inaction of public administration bodies by special commissions for review of complaints is not effective due to the recommendatory nature of their decisions and the optional nature of their creation.

The experience of Western European countries in the field of legal regulation of administrative appeals is analyzed and two main models of administrative appeals are 
singled out: obligatory and optional, each of which is endowed with both advantages and disadvantages.

According to the results of the study, it is needed to improve the current state of legal regulation through the adoption of a single act on the regulation of administrative procedures in general, and administrative appeals in particular.

Key words: administrative appeal, administrative procedure, appeal of acts of public administration bodies, legal regulation of administrative appeal, legal regulation of administrative procedure.

\section{Література}

1. Лученко Д.В. Інститут оскарження в адміністративному праві: автореф. дис. ... докт. юрид. наук : 12.00.07; Національний юридичний університет ім. Ярослава Мудрого. Харків, 2017. 36 c.

2. Пухтецька А.А. Запровадження принципів та стандартів належного урядування у діяльності публічної адміністрації. Наук. зап. НаУКМА. 2010. T. 103. C. 36-40.

3. Державне управління: проблеми адміністративно-правової теоріі та практики / за заг. ред. В.Б. Авер'янова. Kü̈в, 2003. 384 c.

4. Грибок I. О. Оскарження рішень органів виконавчої влади в адміністративному порядку : автореф. дис. ... канд. юрид. наук : 12.00 .07 ; НАН України, Інститут держави $і$ права ім. В.М. Корецького. Київ, 2006. 19 с.

5. Михайлюк Я.Б. Перспективи удосконалення правового регулювання оскарження у сфері надання адміністративних послуг з урахуванням європейського досвіду. Адміністративне право $i$ проиес. 2016. № 2 (16). С. 21-34.

6. Системний звіт. Адміністративне оскарження: поточнии стан та рекомендащії / Рада бізнес-омбудсмена. Київ, 2019. $80 \mathrm{C}$.

7. Dragos D., Marrani D. Administrative Appeals in Comparative European Administrative Law: What Effectiveness? URL: https: / / www.researchgate.net / publication/312705391_Administrative_ Appeals_in_Comparative_European_ Administrative_Law_What_Effectiveness (viewed on August 31, 2020).

8. Лученко Д.В. Про новий проект Адміністративно-процедурного кодексу України в аспекті проблем адміністративного оскарження. Вісник Національного університету «Юридична академія України імені Ярослава Мудрого». 2013. № 1 (12). C. 223-231. 